\section{A $f H$}

Received : 22.12.2015

Revised : 29.04.2016

Accepted : 09.05.2016
Members of the Research Forum

Associated Authors:

${ }^{1}$ Department of Vegetable Science, College of Forestry, Veer Chandra

Singh Garhwali Uttarakhand

University of Horticulture and

Forestry, Ranichauri, TEHRI-

GARHWAL (UTTARAKHAND) INDIA
Author for correspondence : A.C. MISHRA

Department of Vegetable Science, College of Forestry, Veer Chandra Singh Garhwali Uttarakhand University of Horticulture and Forestry, Ranichauri, TEHRIGARHWAL (UTTARAKHAND) INDIA Email : acm24680@gmail.com
THEASIAN JOURNALOF HORTICULTURE

Volume 11 | Issue 1 | June, 2016 | 154-158

Visit us -www.researchjournal.co.in

\title{
Performance of potato varieties under different moisture management systems and planting geometry
}

\section{A.C. MISHRA AND VIVEK PANDEY ${ }^{1}$}

ABSTRACT : Present investigation was conducted during summer-rainy season (March-July) of 2013 in the temperate hills of Tehri-Garhwal, Uttarakhnad (2000 m altitude, 78024' E longitude and $30^{\circ} 18^{\prime} \mathrm{N}$ latitude). Among the treatments planting geometry e.g. single row $(60 \times 20 \mathrm{~cm})$ and paired rows $(15 \mathrm{~cm}$ apart paired rows at $60 \times 20 \mathrm{~cm})$ and irrigation systems viz., furrow and drip with or without dried grass mulching were tested in all possible combinations across the varieties viz., Kufri Girdhari and Kufri Himalini. In paired row planting, tubers of $20 \pm 5 \mathrm{~g}$ weight were planted in $15 \mathrm{~cm}$ apart paired-rows on ridges spaced at $60 \times 20 \mathrm{~cm}$ (centre to centre) as against seed tubers of 40-50 g in single row planting geometry at $60 \times 20 \mathrm{~cm}$ spacing and thus, the seed rate in all treatments was kept constant $(20 \mathrm{q} / \mathrm{ha})$. Results indicated that Kufri Himalini was found to be promising for tuber yield (30.7 t/ha) as affected by combination of planting geometry and irrigation system. Among the cultural practices, paired row planting geometry accompanied with furrow irrigation system $\left(\mathrm{T}_{5}\right)$ was found to be the best cultural combination for tuber yield $(35.2 \mathrm{t} / \mathrm{ha})$. The combination of paired row planting geometry and drip irrigation system $\left(\mathrm{T}_{7}\right)$ was second most important treatment (33.1 t/ha). When cultivars and cultural combination are considered simultaneously, Kufri Himalini exhibited maximum tuber yield in paired row planting system accompanied with furrow irrigation (36.3 t/ha) followed by at par values of Kufri Girdhari in paired row planting system accompanied with furrow irrigation (34.0 $\mathrm{t} / \mathrm{ha}$ ). Based on the results it could be concluded that two varieties of potato Kufri Girdhari and Kufri Himalini responded well to paired row panting geometry. Among the cultural packages paired row planting + furrow irrigation was most promising combination for tuber yield ( $35.2 \mathrm{t} /$ ha) followed by paired row planting + drip irrigation ( $33.1 \mathrm{t} / \mathrm{ha})$ in temperate Himalayas.

KEY WORDS : Paired- row, Planting geometry, Drip irrigation system, Moisture imbibition, Furrow irrigation, Mulching

HOW TO CITE THIS ARTICLE : Mishra, A.C. and Pandey, Vivek (2016). Performance of potato varieties under different moisture management systems and planting geometry. Asian J. Hort., 11(1) : 154-158, DOI : 10.15740/HAS/TAJH/11.1/154-158. 